\section{Small Mammals Increase on Recently Cleared and Seeded Juniper Rangeland}

\section{MAURICE F. BAKER AND NEIL C. FRISCHKNECHT}

Highlight: Small mammal numbers were studied by snap trapping on six areas in Utah where juniper range had been cleared and seeded. On one area, which was trapped both before and for the first 3 years after treatment, numbers of deer mice (Peromyscus maniculatus) and pocket mice (Perognathus parvus) increased greatly in the first 2 years following treatment, then declined sharply to a level which was still above that before treatment. On two areas which were trapped only the first 2 years after treatment, many more small mammals were caught in the second year. Older seedings had about the same number of small mammals as did untreated juniper. Small mammals showed a clear preference for windrowed slash. This was especially true of deer mice and long-tailed voles (Microtus longicaudus). lands by juniper and the ultimate domination of such sites by the pinyon-juniper type (Blackburn and Tueller, 1970) has led to the removal of trees in range rehabilitation programs. Although rodents are known to contribute to the failure of revegetation efforts in some plant types, little is known of small mammals in the pinyon-juniper type or of their reaction to the range renovation findings of a study on small mammaljuniper range relationships in central Utah.

Trees usually are removed from deteriorated pinyon-juniper ranges by dragging chaining commonly is followed by aerial seeding and a second chaining in the opposite direction. An alternative is piling trees with a bulldozer after the first chaining to permit the use of a drill for seeding. Piles of trees are sometimes burned, usually after the new seeding is established. Areas that had been variously treated in these ways were sampled to evaluate the effects of tree removal and seeding and of different slash disposal methods on the numbers and kinds of small mammals.

The authors are wildlife biologist, Bureau of Sport Fisheries and Wildlife, Provo, Utah, and range scientist, Intermountain Forest and Range Experiment Station, Forest Service, U. S. Department of Agriculture, Ogden, Utah.

Manuscript received February 11, 1972.

\section{Methods}

Six areas were studied in the foothills and lower slopes of the Tintic and Sheep-
Traplines in experimental strips

Aug. 24-26, 1966

Chained-windrowed-seeded 3
Untreated ${ }^{2}$

July 19-21, 1967

Untreated

Chained-seeded-chained

Chained-windrowed-seeded ${ }^{4}$

Oct. 2-4, 1968

Untreated

Chained-seeded-chained

Chained-windrowed-seeded ${ }^{3}$

Chained-windrowed-seeded 4

19

9

8

9

2

2

\section{9}

118

107

112

Sept. 30-Oct. 2, 1969

Untreated

Chained-seeded-chained

Chained-windrowed-seeded ${ }^{3}$

Chained-windrowed-seeded ${ }^{4}$

Sept. 30-Oct. 2, 1970

Untreated

Chained-seeded-chained

Chained-windrowed-seeded ${ }^{3}$

Chained-windrowed-seeded 4

Traplines in untreated juniper stands

Nov. 19-21, 1968

$\begin{array}{ll}\text { No. } 1 & 15 \\ \text { No. } 2 & 13 \\ \text { No. } 3 & 22 \\ \text { No. } 4 & 13\end{array}$

21
2270 trap nights, all others were 180 .

3 Traps along windrow.

4 Traps between two windrows.
The invasion of sagebrush-grass rangeprocess. This paper reports preliminary a heavy anchor chain over them. The first

rock Mountains west of Nephi and south of Vernon, Utah. The most intensive study was done at and near the Benmore Experimental Range, which has been described by Frischknecht and Harris (1968). At Benmore, a pretreatment survey was made in 1966 using one line of small snap traps having 30 stations and 90 traps for 3 nights. Other traplines were composed of 20 stations 50 feet apart, determined by pacing; each station had one rat trap and two museum special traps. Except in 1967, each line was run for 3 nights. Sets were made each evening, and all animals were removed the next morning.

The following four treatments of deteriorated pinyon-juniper range were sampled for small mammals: (1) untreated, usually old juniper stands with little understory; (2) chained two ways and seeded; (3) chained, windrowed, and seeded; and (4) chained, windrowed, seeded, and the windrows burned. Spacing of the windrows varied, but minimum distance between windrows was approximately 300 feet. Thus, where traplines were set along and between windrows, the traplines were 150 feet, or more, apart.

The clearing at Benmore was done for experimental purposes and was in 0.1mile-wide treated and untreated strips.

Table 1. Numbers of small mammals caught at Benmore Experimental Range ${ }^{1}$.

\begin{tabular}{llclc}
\hline \hline & & & Long- & Other \\
Time of trapping \& & Deer & Pocket & tailed & small \\
type of treatment & mice & mice & voles & Rabbits \\
\hline
\end{tabular}

$\begin{array}{lllll}30 & 0 & 0 & 2 & 0 \\ 25 & 7 & 0 & 0 & 1 \\ 17 & 7 & 0 & 0 & 1 \\ 16 & 7 & 0 & 0 & 0\end{array}$

$\begin{array}{lllll}27 & 5 & 0 & 0 & 0\end{array}$

$27 \quad 2$

$37 \quad 1$

4

0

0

$0 \quad 1$

${ }_{2}$ Tree removal and seeding done in fall and winter of 1966-1967.

\begin{tabular}{|c|c|c|c|c|}
\hline 15 & 0 & 0 & 0 & 0 \\
\hline 13 & 0 & 0 & 0 & 1 \\
\hline 22 & 0 & 1 & 0 & 4 \\
\hline 13 & 0 & 0 & 0 & 0 \\
\hline
\end{tabular}


All other samples were taken from block treatments of 300 acres or more, which had been cleared for management purposes.

The chi-square test was used to test differences for significance. In instances where the number of trap nights was not the same on different areas, the data were reduced to the number of trap nights needed to catch one mouse before the chi-square test was applied. In the discussion, any statement that expresses a difference between or among results is based on statistical significance at the $95 \%$, or higher, level of confidence.

\section{Results and Discussion General}

During 7,350 trap nights, 1,321 small mammals of 13 species were taken. There were 1,097 deer mice (Peromyscus maniculatus), which comprised $83 \%$ of the total number caught and at least 50\% of each catch, except one. Other species

Table 2. Number of small mammals caught in five study areas in central Utah.

\begin{tabular}{|c|c|c|c|c|}
\hline $\begin{array}{l}\text { Area, year of treatment, } \\
\text { and sampling dates }\end{array}$ & $\begin{array}{l}\text { Deer } \\
\text { mice }\end{array}$ & $\begin{array}{l}\text { Pocket } \\
\text { mice }\end{array}$ & $\begin{array}{l}\text { Long- } \\
\text { tailed } \\
\text { voles }\end{array}$ & $\begin{array}{c}\text { Other } \\
\text { small } \\
\text { Rabbits }\end{array}$ mammals \\
\hline
\end{tabular}

Beckstrom, 1966-1967

Aug. 1, 1967

Untreated

Chained-seeded-chained

Chained-windrowed-seeded ${ }^{1}$

$0 \quad 0$

$6 \quad 0$

Nov. $12-14,1968$

Untreated

Chained-seeded-chained

Chained-windrowed-seeded 1

9
40

18

Lofgreen No. 1, 1966-1967

July 29,1967

Untreated

Chained-seeded-chained

Chained-windrowed-seeded ${ }^{2}$

Chained-windrowed-seeded ${ }^{3}$

Oct. 16-18, 1968

Untreated

Chained-seeded-chained

Chained-wind rowed-seeded ${ }^{2}$

Chained-windrowed-seeded ${ }^{3}$

0

0

0

0
0
0

$\begin{array}{ll}0 & 0 \\ 0 & 2 \\ 0 & 2 \\ & \\ 0 & 6 \\ 1 & 5 \\ 0 & 2\end{array}$

Lofgreen No. 2, 1967-1968

Oct. 30-Nov. 1, 1968

Chained-wind rowed-seeded ${ }^{2}$

Chained-windrowed-seeded ${ }^{3}$

24

2
6

12

6

Birch Canyon, 1965

Oct. $23-25,1968$

Chained-wind rowed-seeded ${ }^{2}$ Chained-wind rowed-seeded ${ }^{3}$

Oct. 22-24, 1969

Chained-windrowed-seeded ${ }^{2}$

Chained-windrowed-seeded ${ }^{3}$

Boulter, 1956

Oct. 23-25, 1968

Chained-windrowed-seeded ${ }^{2}$ Chained-windrowed-seeded ${ }^{3}$

Oct. 22-24, 1969

Chained-windrowed-seeded ${ }^{2}$

Chained-windrowed-seeded ${ }^{3}$

were represented by: 93 Great Basin pocket mice (Perognathus parvus), 37 long-tailed voles (Microtus longicaudus), 28 western harvest mice (Reithrodontomys megalotis), 27 chisel-toothed angaroo rats (Dipodomys microps), 12 's cottontails (Sylvilagus nuttallii), ks (Eutamias dorsalis), 2 rock leucogaster). The methods used were not well adapted to trapping rabbits and hares, and the results probably do not reflect their numbers or importance. Indeed, the biomass of the 12 cottontails might have approximated half that of all the deer mice caught and exceeded the biomass of all other small mammals caught.

$\begin{array}{lllll}11 & 0 & 5 & 0 & 1 \\ 14 & 1 & 0 & 0 & 2 \\ & & & & \\ 17 & 0 & 2 & 0 & 0 \\ 13 & 0 & 0 & 0 & 0\end{array}$

\section{Effects of Tree Removal and Reseeding}

At Benmore the average catch on all treatments was less in 1967 than before treatment in 1966 (Table 1), but trapping success on the untreated strip in 1967 was not different from the pretreatment sample. Because the 1967 sample was taken earlier in the summer and nearby samples in sagebrush-grass range (Black, 1968) showed an even greater decline in 1967 than occurred on the treated strips, the 1967 data from the strips could be interpreted as no change or even a slight increase. In the 2 nd year after treatment (1968), there was a dramatic increase in the catch of deer mice and pocket mice on the Benmore strips, but similar high numbers were not indicated by the catch from four traplines in untreated juniper in the same vicinity. In the $3 \mathrm{rd}$ and 4 th year after treatment, the catch at Benmore dropped to a much lower level, but remained higher than before treatment.

Results from the Beckstrom and Lofgreen No. 1 areas in the first 2 years after treatment (Table 2) showed the same trend as those from Benmore; there was a sharp increase in the 2 nd year after treatment. However, 2 nd year catches on these large block treatments did not increase as much as at Benmore. Apparently the high degree of edge afforded by the narrow strips of different treatments at Benmore created a generally favorable habitat for small mammals. The greater number of "other small mammals" caught at Lofgreen No. 1 is probably related to the sandier soil of the area. Kangaroo rats and harvest mice accounted for most of this difference.

The data from Birch Canyon, 3-4 years after treatment, and Boulter, 12-13 years after treatment (Table 2), suggest that numbers of mice may continue to decline into the 4th year after treatment but may become stabilized at a relatively low level soon thereafter. Trapping success on old seedings with windrowed slash did not differ from that on large units of untreated juniper in 1968.

\section{Effects of Slash Disposal}

On the Benmore strips, in the 4 years following treatment, the summed data for all small mammals revealed no differences due to treatment. Data from individual years indicated a preference for heavier cover in some, but not all, situations. In the larger clearings of other areas that had been treated as recently as 2 years before sampling, a preference was shown for slash cover-especially that of windrows

${ }_{1}^{1}$ Windrows burned.

${ }_{2}^{2}$ Traps along windrow.

3 Traps between two windrows. 
(Table 2). At Beckstrom, more mice were caught on the chained area than either the untreated or burned areas. At Lofgreen No. 1, deer mice indicated a preference for windrows, but not scattered slash, or they avoided open areas between windrows. At Lofgreen No. 2 in the $1 \mathrm{st}$ year after treatment and at Boulter and Birch Canyon, where treatments had occurred 3 or more years before sampling, no effect of windrows was apparent.

The few pocket mice caught showed no preference for treatment except on the Benmore strips in 1968 , when more were caught in the scattered slash of the chained-two-ways strip.

Voles showed a strong preference for heavy cover. Thirty-four of 37 long-tailed voles caught in all areas were caught adjacent to windrows, and one was caught in a chained area having heavy cover. These microtines are characteristically found in heavy brush-grass cover but not in typical "bare ground and juniper" sites. It seems quite clear that piling trees creates vole habitat.

A study of rodent response to juniper removal and range seeding was reported by Turkowski and Reynolds (1970). They found from 1.2 to 4.0 times as many rodents on treated areas as on untreated plots, but trapping did not start until 3 years after treatment. Thus, a peak population such as we found in the 2nd year would have been missed in their study.

\section{Literature Cited}

Black, Hal Lunt. 1968. Population of small rodents in relation to grazing by cattle on foothill ranges. M.S. Thesis, Univ. of Utah, Salt Lake City, Utah. 56 p.

Blackburn, Wilbert H., and Paul T. Tueller. 1970. Pinyon and juniper invasion in black sagebrush communities in east-central Nevada. Ecology 51:841-848.

Frischknecht, Neil C., and Lorin E. Harris. 1968. Grazing intensities and systems on crested wheatgrass in central Utah: Response of vegetation and cattle. U.S. Dep. Agr., Forest Serv. Tech. Bull. 1388. 47 p.

Turkowski, Frank J., and Hudson G. Reynolds. 1970. Response of some rodent populations to pinyon-juniper reduction on the Kaibab Plateau, Arizona. Southwestern Natur. 15(1):23-27.

\section{Summer Meeting}

Fort Lewis College, Durango, Colo. July $18-20$

Watch for details in April issue of Rangeman's News 